\title{
The Asian Carp Threat to the Great Lakes: An Analysis of Alternatives for Preventing Asian Carp Migration
}

\author{
By Nicole D. Rodriguez
}

The ecosystems of the United States face numerous threats to sustainability arising from the introduction and proliferation of non-native, invasive plants and animals. One example is that of Asian carp, a species of invasive fish that is devastating native ecosystems in some inland US waterways. Current concerns center on the migration of Asian carp into the Great Lakes and how that could be particularly detrimental to the ecosystems and natural stability of the area. This paper examines the policy alternatives for halting the advance of Asian carp before they reach the Great Lakes, and recommends that electric barriers be used as the primary means of deterrent. However, such barriers are not a universally-applicable solution, and further research on securing US waterways from the Asian carp threat is required.

The views herein are those of the author and are not to be construed as official or reflecting the views of the Commandant or of the US Coast Guard.

\section{Introduction}

The Great Lakes hold 20 percent of the world's freshwater and are home to over 80 threatened or endangered species. They are more than just a beautiful natural resource and source of freshwater, they are also important for the economies of the United States and Canada, which rely on them for commercial shipping, transportation, fishing and recreation to sustain communities and quality of life (Brookings 2007). With this precious natural resource comes a responsibility to ensure its sustainability and health for all users to enjoy. Despite their beauty, the Great Lakes are not immune to some of the environmental dangers found elsewhere in the United States. One of the most difficult environmental problems facing the United States today is the issue of invasive species. Pertinent to this analysis will be a discussion of aquatic invasive species (AIS). These invasive species are alien, have no natural predators in the United States, and often bring in diseases. With no population controls, once introduced, AIS quickly propagate and gain a foothold in their new ecosystem. Once an AIS population has established itself, it becomes entrenched in the ecosystem, forever altering the delicate, life-sustaining balance of that system. AIS often cause a ripple effect, not only crowding out native species, but destroying natural habitats. They can forever alter a waterway, changing what life it can sustain and destroying the livelihoods of people who depend on it.

For example, the Snakehead fish, native to Africa and Asia, is the fish of horror movies. It can grow up to three feet in length and is a toothy beast that can breathe air and wiggle across land in short bursts, and is able to attack small rodents. The Snakehead is a top-level predator, 
capable of eating all other species of fish in a waterway. Currently, Snakeheads are threatening to establish a firm hold in the freshwater rivers of the Chesapeake Bay. If this happens, they will crowd out and eat the native fish populations, damaging fishing industries and creating an ecological ripple effect in the food chain (Mayell 2002).

There are over 180 invasive species found in the Great Lakes; however, only a handful pose a dangerous enough threat to warrant serious and immediate action to reduce their spread. Great Lakes communities spend over \$30 million annually to eradicate just two of the more destructive invasive species, the Ruffe fish and the Zebra mussel (ANSTF n.d.). However, even with such expenditures, the dominance of Ruffe fish over indigenous fish species remains a problem. Zebra mussels, too, are taking over native mussel species. Zebra mussels spread rapidly by clinging to vessel hulls and, even though they were introduced to the Great Lakes in 1988, already have established themselves as far as California. Because they are so prolific they block out the food sources of freshwater mussels and wipe them out. In addition, they clog pipelines and water intakes, and infest docks and boats. The economic cost of Zebra mussels is estimated at over $\$ 500$ million a year in expenses related to cleaning water intakes, boats, docks, and wastewater plants (Hoddle 2009).

The most immediate threat to the Great Lakes, however, is not the Ruffe fish or the Zebra mussels. That threat is the Asian carp, which threatens to decimate the ecology and economy of the Great Lakes. The United States Fish and Wildlife service has stated that the Asian carp are "probably the single greatest threat in our country to our native wildlife" (Eilperin 2010).

Asian carp were introduced into the United States as a pest control measure for catfish aquaculture farms in Louisiana in the 1970s. During the 1990s, carp escaped during flood periods and have spread and propagated throughout the Mississippi river basin. In fact, in some parts of the basin, such as the Illinois River, Asian carp now account for the majority of fish (Walsh 2010). The carp's northward migration now places them at the entry to the Great Lakes' ecosystems.

The following is an analysis of Asian carp containment efforts at one specific point of entry into the Great Lakes: the Chicago Sanitation and Ship Canal. Three species are targeted: the silver carp, bighead carp, and the black carp (ACWG 2010). For the purposes of this paper the term Asian carp is intended to refer to those three species. As with nearly all AIS species, Asian carp are here to stay. Once an invasive species becomes established, total eradication becomes unrealistic. Efforts to eradicate established populations of AIS, are costly and ineffective at achieving the eradication goal. A viable AIS strategy, therefore, is more focused on managing the species throughout its lifecycle, minimizing its effects on local populations, and preventing additional spread (ACRCC 2008). This analysis takes into consideration the 2011 Asian Carp Control Strategy Framework and focuses specifically on pending legislation and active programs designed to stop the migration of Asian carp into the Great Lakes via the Chicago Sanitary and Ship Canal.

\section{A Fishy Problem}

Asian carp grow in excess of five feet and can weigh upwards of 100 pounds. They are voracious eaters, able to consume over 20 percent of their body weight each day. With a life cycle of 20 or more years, they quickly and easily strip the food sources from, and thus crowd out, native aquatic species. As one example, there is grave concern among experts that the Asian carp will hasten the extinction of the Lake Sturgeon fish in the Great Lakes. The population of the Lake Sturgeon is less than one percent of original numbers and, should the Asian carp enter the Great 
Lakes, both species would directly compete for a limited food supply. Asian carp, specifically silver carp, pose a safety risk to some boaters in that the fish have the ability to "fly," leaping up to 10 feet above the water and occasionally striking boaters (Plumer 2010).

The threat from AIS to the Great Lakes cannot be understated. Asian carp have no natural predators in US waters, so if these fish enter the Great Lakes they will severely impact the entire ecosystem and potentially destroy a $\$ 7$ billion a year sport fishing industry. Such an outcome has already occurred in some popular fishing pockets in the Mississippi River. The United States Fish and Wildlife Service believes that, given the large migration area in the Great Lakes, Asian carp would quickly establish a dominant population
(Carducci 2009). This issue is so pressing that in December 2010, the Asian Carp Prevention and Control Act was signed into law. This Act makes it unlawful to import Asian carp, specifically the bighead carp, into the United States by making it an injurious species under the Lacey Act (P.L. 111-307). While this Act prevents the importation of bighead carp and regulates the interstate transfer of these fish, it does not address the problem of the already established Asian carp population. Additionally, the United States has not yet developed an overarching strategy for dealing with AIS, which often cross jurisdictional boundaries.

\section{Chicago Sanitary and Ship Canal}

This analysis focuses specifically on the Chicago Sanitary and Ship Canal

Figure 1: Chicago Sanitary and Ship Canal.

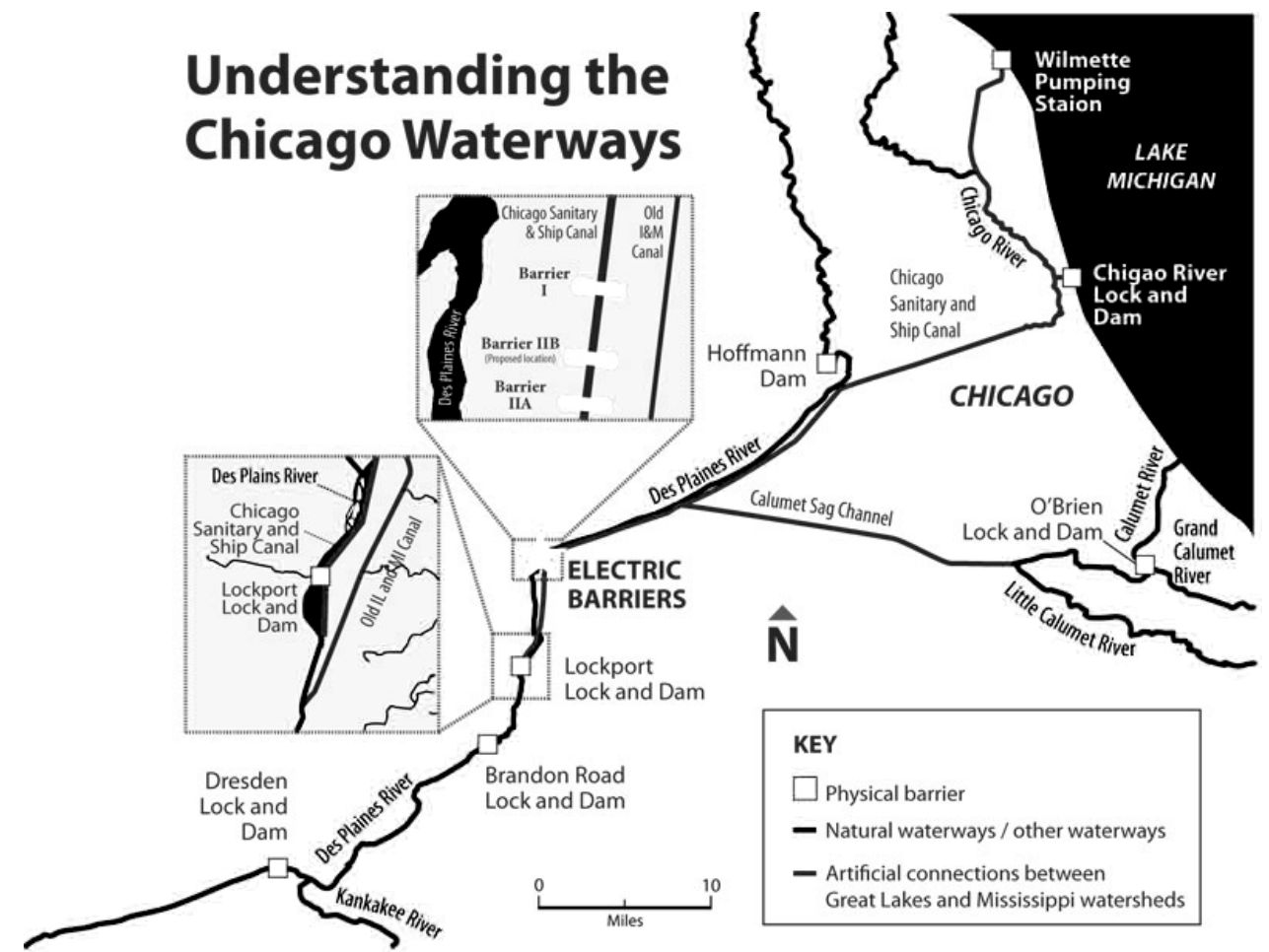

Source: Michigan Sea Grant 2011. 
(CSSC) and efforts to prevent Asian carp from moving beyond man made barriers within the CSSC. Asian carp likely would be introduced into the Great Lakes ecosystem via man-made artificial connections through CSSC. Regarding ballast water release, concerns do not exist of Asian carp being introduced into the Great Lakes in this manner. Ballast water management is beyond the scope of this analysis and will not be discussed. Asian carp have been discovered in nearly all areas of the CSSC, making their migration into the Great Lakes inevitable if mitigation measures do not occur. Given their aggressive ability to spread quickly, and the fact that the CSSC and the Great Lakes are intertwined ecologically, economically, and politically with billions of dollars at stake, the severity of this pending invasion cannot be overstated. While the problem has been debated for some time, there is now an urgent need to act quickly to avoid potential ecological and economic ruin of the Great Lakes.

Construction of the CSSC was completed in 1900, and completion of the locks and dams to establish a shipping link between the Great Lakes and the Mississippi River occurred in 1907. The Calumet-Sag Channel was linked to the CSSC upon its completion in 1922, effectively bridging the Continental Divide and reversing the flow of the Chicago River so that it emptied into the Mississippi River Basin (Chicago Historical Society 2005). As shown in Figure 1, the CSSC connects to Lake Michigan through the Wilmette and Chicago Locks directly abutting Lake Michigan, and the O'Brien Lock through the Calumet-Sag Channel. The CSSC not only provides an affordable way to move goods over water, but it also acts as a flood control system for the Chicago basin (CHS 2005).

\section{Stakeholders}

Asian carp do not just affect the fishing industry on the Great Lakes, but numerous other stakeholders. Efforts to control and reduce the population involve a wide range of federal, state, and local regulatory and enforcement agencies in addition to environmental and private organizations. The issue has created a serious political rift between the states of Michigan and Illinois. Competing interests about how to treat the CSSC have made it difficult to develop fair and feasible Asian carp control strategies between the two governments.

In 2009, Michigan filed a lawsuit against Illinois and the United States Army Corp of Engineers (USACOE) asking for a preliminary injunction to close the locks from the CSSC into Lake Michigan. While the United States Supreme Court rejected the preliminary injunction, the matter is not yet settled (Rizo 2010).

Illinois and the American Waterways Operators (AWO) strenuously oppose the closing of the CSSC for a multitude of reasons. The permanent closing of the lock system would effectively cut off the only water transportation route from the Great Lakes to the Mississippi River. Each year over $\$ 4$ billion worth of commodities travels through these locks, including much of the Chicago area's energy products such as coal and petroleum. Dr. Joseph Schwieterman's 2010 study on the economic effects of closing the CSSC lock system estimates that it would have a $\$ 1.3$ billion impact on commercial shippers and barge operators, including a loss in transportation savings that would be directly passed on to the end-users of shipped goods, resulting in much higher costs for consumers in basic commodities and utilities. Further, Illinois estimates a loss of $\$ 4.7$ billion over twenty years if the CSSC is closed (Schwieterman 2010). Delivery of goods would also be severely delayed if shippers had to rely on overlandonly means of transportation. Illinois also contends that closing the locks would negatively affect jobs and property in the Chicago area (ACWG 2010).

Michigan asserts that the only 
way to ensure that Asian carp do not enter the Great Lakes is to close the CSSC, creating an ecological separation at the Chicago diversion between the Great Lakes and the Mississippi River. Michigan estimates that the cost to Illinois should the CSSC be closed is $\$ 70$ million, while if Asian carp enter the lakes it has the potential to disrupt a $\$ 4.5$ billion fishing industry. $\mathrm{Al}-$ though it is difficult to predict exactly what sort of impact the Asian carp will have on the Great Lakes ecosystem, it is estimated that they may also destroy nearly half of the local federal endangered species and sea grasses needed to sustain aquatic life and ensure a healthy Great Lakes ecosystem (ACWG 2010).

\section{Criteria}

This analysis will evaluate three specific alternatives used to prevent the introduction of Asian carp into the Great Lakes via the CSSC vector: closure of the locks on the CSSC to achieve ecological separation; the use of an electric underwater barrier to repel the carp; and a commercial harvesting (corral/capture/kill) method. These alternatives will be evaluated primarily on their effectiveness and feasibility to execute. Equity of the impacts of each alternative on stakeholders will also be evaluated; however, the effectiveness and feasibility of implementing these alternatives are more important for the purpose of this analysis. This weighting is intended to mitigate the fact that what the author feels are potentially biased impact studies are currently conducted by stakeholders that have a self-vested interest in the outcome, and are often at odds with each other over what may be the most effective methods of Asian carp control. These three criteria were chosen because they are the federal government's most widely accepted means of evaluating proposed laws regarding aquatic invasive species. This analysis focuses only on active and/or well-documented control methods. Acoustic barriers and seismic technology are still in the early stages of development and study, and as such, have limited available information regarding the criteria set forth in this analysis.

\section{Effectiveness}

Identifying a policy to prevent the migration of Asian carp into the Great Lakes is the most important goal of effectiveness. Once the invasive species is introduced, any efforts to control its impacts may be largely ineffective. Since a small percentage of Asian carp could easily establish themselves into a larger population, alternatives that have the closest to 100 percent success rate of halting fish migration will be considered the most effective.

\section{Structural Feasibility}

Structural feasibility will be analyzed on the degree of structural, physical and/or engineering changes that are necessary to control Asian carp migration and any related health and safety impacts that may result from the proposed alternative.

\section{Political Feasibility}

Political feasibility will evaluate any potential legal hurdles and constituent opinion. Due to the fact that the Asian carp threat is moving at a quick pace, and with the interconnectedness of the issue to multiple stakeholders, official government studies on the feasibility and impacts of proposed alternatives, such as ecological separation between the watersheds, have not been completed at this time. This makes determining political feasibility based soley on economic impact, cost to government, and constituent populations impossible.

\section{Equity}

Due to the existence of diametrically opposed stakeholders, there is no foreseeable win-win solution for all involved to the Asian carp threat. Any alternative will negatively impact some stakeholders. Fully benefiting one stakeholder group at the total expense of an- 
other would be the most unacceptable alterative. Alternatives will be evaluated as to how they spread the negative impact across stakeholders, and their efforts to minimize those impacts. While the federal government, via USACOE, owns and controls the CSSC, stakeholder interest is varied with multiple decision makers having say. There are eighteen domestic jurisdictions/authorities with a stake in Asian carp and Great Lakes AIS eradication and control. These include eight federal agencies, such as United States Fish and Wildlife Service and USACOE, and ten state agencies, such as the Illinois Department of Natural Resources. This number does not reflect commercial stakeholders such as commercial shipping interests, recreational waterways users, or international stakeholders such as Canada, which has a shared border in the lakes. Lost value and compounded financial impact to stakeholders are a majority of what comprises the equity criterion; however, no independent cost review has been conducted at this time. Because of this, the criterion of equity is especially important and must be included in the analysis of alternatives.

\section{Alternatives}

The electric barrier and commercial harvesting (corral/capture/kill) alternatives proposed were chosen for analysis because they are the current means of controlling the migration of AIS. The alternative of closing the CSSC locks was included because there is a request before the $\mathrm{Su}-$ preme Court seeking this alternative. In addition, there have been several recent attempts at legislation to close the CSSC locks, including a budget bill amendment to deny the USACOE funding to operate the CSSC locks (Flesher 2011). Each of the alternatives is described here and evaluated on the above criteria.

\section{Alternative 1: Electrical Barriers}

There are two electric underwater barriers operating in the CSSC. The barriers were built and are operated by the
USACOE. Barrier I, as it is known, currently operates at two volts per square inch and is designed to prevent Asian carp from migrating north of the barrier, acting as an electric fence. The barrier is located downriver in the CSSC structure so as to prevent carp from migrating into Lake Michigan through both the Chicago River and the Calumet-Sag Canal and accompanying locks.

A third electrical barrier (Barrier IIB) and dedicated power station have been constructed just upstream of the Barrier IIA to prevent further migration of Asian carp. Barrier IIB is currently undergoing safety testing.

\section{Effectiveness}

Barrier I was found to be ineffective at controlling the migration of Asian carp above the electric fence at a voltage rate of one volt per square inch. Barrier I and Barrier IIA currently operate at a voltage of two volts per square inch. The increased voltage has been found to be 95 percent effective at repelling the Asian carp. Barrier I and IIA are located 1050 feet apart and work in conjunction with each other (Shea 2009). Barrier IIB rests between Barrier I and IIA and is expected to augment the other two barriers by providing for redundancy in the system and to allow for maintenance. Barrier IIB also provides the ability to temporarily repel fish should the other barriers suffer failure (Egan 2010). Since Barrier I was built as an initial test, it is the intent of USACOE to remove Barrier I in a few years and replace it with a more permanent facility.

The electric barrier alternative has been independently studied in-depth and has been found to be the most effective means of repelling Asian carp in comparison to other means, including Rotenone applications, targeted removal operations, and spawning interruptions (ACWG 2010). The effectiveness of the electric barrier has not been compared against the effectiveness of lock closure. The effect of steel hulled vessels acting 
as electric "shields" allowing fish to pass through the barrier is also being studied (ACWG 2011).

\section{Structural Feasibility}

Since electric barriers are already in operation, there are few additional structural or engineering concerns regarding building and operation of the barriers. The barriers operate on water-cooled switches that draw water from the canal. Because water temperature may not be adequately cool enough to prevent overheating of the barriers, chillers have been installed to prevent overheating. In addition, variations in water salinity affect the ability keep the barriers cool enough to operate. To address this issue, a separate power station was constructed as part of Barrier IIB (Sea Grant Institute. Aquatic Nuisance Species. n.d.).

USACOE and the United States Coast Guard (USCG) have raised serious concerns regarding the safety of the electric barriers. There is a significant risk of shock and drowning should a person fall overboard or into the river in the vicinity of the electric barrier. USCG has restricted the types of vessels that can transit though the electric barrier, and specifically restricts all recreation boats under 20 feet and personal watercraft. Improperly installed equipment on a vessel may become electrified and kill or seriously injure people on the vessel, regardless of an individual's water contact. There is no agency that will perform rescue operations within the electric barrier zone. There is also concern that electrical arcing or an electrical spark can cause dangerous and flammable cargoes to ignite. USACOE and USCG have worked with commercial vessel operators to reduce this risk through restrictions during transit operations when the electric barrier is in operation (USCG. Fish Barrier Information. n.d.).

\section{Political Feasibility}

Support for the electric barrier is high among nearly all stakeholders. How- ever, Michigan has not supported the barrier over concerns that it is not 100 percent effective at preventing Asian carp migration. Michigan has been joined by other Great Lakes states in lobbying Congress for total ecological separation between the lakes and the CSSC. In testimony before Congress, the Wisconsin Department of Natural Resources indicated that while it supports ecological separation through lock closure, it is open to other effective means of controlling Asian carp migration, including the maximum use of current electric barriers and construction of additional barriers should adequate funding be secured (Frank 2010).

While Barrier I was funded at 100 percent by the federal government, Barrier IIA was federally funded at a rate of 75 percent with the remaining funds coming from Illinois' Department of Natural Resources and the Great Lakes Restoration Fund, which is a collaborative pool of money by all Great Lakes states (Shea 2009). Barrier IIB and accompanying infrastructure were funded through the American Recovery and Restoration Act. While there is high constituent support for the electric barrier, this support would be in jeopardy if federal funding were decreased or USACOE no longer operated the barriers, forcing Illinois to pay for the majority of the cost of constructing and operating the barriers. Likewise, requiring other Great Lakes states to assist in paying for the barriers would reduce necessary political support among these states. Based on high current levels of Congressional support for funding, and current bi-partisan approved control strategies include use of the electric barrier, it is unlikely that the funds to operate or maintain the electric barriers would be significantly reduced or eliminated.

\section{Equity}

Assuming the electric barrier continues to be effective, the impact to stakeholders is minimal. Federally, the USACOE fiscal year 2012 budget requests $\$ 10.6$ mil- 
lion in operation and maintenance of the fish dispersal barrier (USACOE 2012). Those stakeholders most negatively impacted by the electric barrier include recreational boaters and fishermen who are restricted from transiting through the barrier. Commercial haulers of chemical and fuel cargoes are economically impacted by having to adjust and limit their transports, adding additional costs. In addition, restrictions on navigation impact all commercial traffic with commercial operators paying upwards of $\$ 1200$ a transit to secure the necessary dispersal barrier escort vessels (Muench 2010). However, commercial shippers support the barrier in lieu of lock closure.

Alternative 2: Lock Closure on the Chicago SANitary and Ship CANal

Free flow of water between Lake Michigan and the CSSC occurs via the three locks in the CSSC and pumping/ flood control stations. An interesting dynamic of the Asian carp mitigation process is that the issue of lock closure has become politicized. In January of 2010, US Representative Dave Camp (R-MI) introduced the Close All Routes and Prevent Asian Carp Today Act of 2010. This bill would have forced the USACOE and Illinois to close all locks from the CSSC into Lake Michigan (Thomas HR 4472). Numerous environmental groups, including the Natural Resources Defense Counsel, have come out in favor of lock closure as a means to ensure ecological separation of Asian carp to the lakes. Ecological separation means no transfer or movement of organisms between two watershed basins (ACRCC 2008). While technically this does not necessarily mean lock closure, in the public sphere this is what is implied.

\section{Effectiveness}

Currently there have been no neutral-based studies done on the effectiveness of closing the locks to prevent migration of fish. As part of the Great Lakes and Mississippi River Inter-Basin
Study, the USACOE will evaluate ecological separation. However, this report is not due until September 2011 (ACWG 2011). Closing only the locks would be ineffective in preventing Asian carp migration because even when locks are completely closed there is water transfer around the gates. The design of the CSSC allows for numerous cross-water connections beyond the locks including pumping stations and sluice gates. Because of these crosswater connections beyond the locks, total ecological separation cannot be achieved by lock closure alone and would require additional and modified infrastructure (ACRCC 2008).

Only total ecological separation at the Chicago diversion would be effective at preventing Asian carp from migrating into the Great Lakes from the CSSC vector (Brammeier et al. 2008). There are currently 14 different waterway diversions into and between all the Great Lakes, reducing the effectiveness of lock closure by leaving 13 other diversions (ACWG 2010). In addition, there are 18 areas where a medium to high risk of potential AIS, specifically Asian carp, transfer exists. In particular, Eagle Marsh in Ft. Wayne, IN has been identified as an area of immediate concern as a pathway for Asian carp to reach Lake Erie (USACOE 2010). Thus ecological separation achieved at only the CSSC vector would not be 100 percent effective at preventing AIS introduction via the other cross points.

\section{Structural Feasibility}

It would be relatively easy for the USACOE to close the locks manually and sluice gates and make them more watertight. However, permanent closure of the locks and sluice gates would drastically affect flood prevention and control for the Chicago basin. The CSSC was designed as a flood mitigation and wastewater canal to prevent contaminated drinking water from flowing through the city and into Lake Michigan. The CSSC was an engineered reversal of the flow of the Chicago 
River so that it now flows south through the Des Plaines River and through the Mississippi.

The CSSC allows for reverse flow of water back into Lake Michigan to prevent flooding and contamination. Currently, the sluice gates control the flow and volume of water and wastewater in and out of the Chicago area (Schwieterman 2010). The USACOE estimates that closing the locks and sluice gate system would significantly raise the water levels during storm events, leading to flooding throughout downtown Chicago and along the North Branch of the Chicago River. Flooding would be far more serious than was seen during the 2008 floods where 2.9 million gallons of storm water was allowed to freeflow back into Lake Michigan. Even separation barriers installed would damage existing levee systems and cause flooding (Wisconsin v. Illinois mod. 2010).

\section{Political Feasibility}

The Great Lakes states of Michigan, Wisconsin, Ohio, New York, and Minnesota strongly support lock closure and ecological separation as the primary means of ensuring Asian carp do not enter the lakes. Constituent opinion within the aforementioned states is strongly in support of lock closure. Illinois is opposed to this alternative (Brammeier et al. 2008).

In 2009, Michigan's Attorney General filed a petition in the United States Supreme Court to reopen the 1930 case of Wisconsin v. Illinois to have the CSSC locks permanently closed. In 1930, the United States Supreme Court ruled that Chicago could continue its diversion of lake water; however, it left open the possibility that the ecological separation could be mandated should the Chicago diversion be shown to cause irreparable harm the Great Lakes (Wisconsin v. Illinois mod. 1967). While there is legal standing to request lock closure, the United States Supreme Court has sided with Illinois and has refused to hear the injunction making a United States Supreme Court ruling for lock closure unlikely.

In 2010 Michigan Representative Dave Camp (R-MI) and Senator Debbie Stabenow (D-MI) introduced the Close All Routes and Prevent Asian Carp Today Act (H.R.4472; S.2946). In 2011, Rep. Camp proposed a budget bill amendment to deny the USACOE funding to operate the CSSC locks (Flesher 2011). In addition, Senator Stabenow intends to reintroduce the Permanent Prevention of Asian Carp Act (S. 3553) (Stabenow n.d.). Pennsylvania, Ohio, New York, Wisconsin and Michigan have all lobbied for the legislation along with such environmental groups as The Natural Resources Defense Counsel (H.R. 4472). Environmental and nongovernmental organizations such as Natural Resources Defense Council, National Wildlife Federation, and the Alliance for the Great Lakes all favor ecological separation as the only acceptable, 100 percent effective solution to preventing AIS transfer into the Great Lakes. In addition, infrastructure changes required to achieve this separation would also address existing environmental concerns regarding Chicago's wastewater treatment (Henderson 2010). If legislation were to pass to close the CSSC, it would likely face costly court challenges.

\section{Equity}

Both Michigan and Illinois have conducted individual studies to estimate the cost of closing the CSSC with vastly different results. Michigan has estimated the costs in increased transportation and economic losses to Illinois at $\$ 70$ million a year. Michigan contends that this is an acceptable loss compared to a potential loss of $\$ 7$ billion in fishery revenue for the Great Lakes states. The Illinois Chamber of Commerce disagrees with the Michigan study, and has estimated Chicago's economic losses to equal $\$ 4.7$ billion over the next 20 years. Part of the reason for the large difference in estimates is that the Michigan study does not take into account flood control measures that Illinois would 
have to implement, nor does it take into account the need to create new infrastructure and potentially alter shipping routes (Taylor 2010).

The impact to Illinois stakeholders includes an estimated \$95 million in shipping and \$30 million in infrastructure costs, plus flood prevention measures that would cost \$375 million. In the United States Supreme Court case of Wisconsin v. Illinois, AWO, the organization for commercial shippers on the rivers, submitted testimony that lock closure will be devastating to their industry, stating that several maritime industries including certain shippers, tour boat and commercial salvage operations, would be forced out of business, resulting in over $\$ 18$ billion in losses (Wisconsin v. Illinois mod. 2010). This alternative clearly favors the Great Lakes states' interests over those of Illinois and Chicago.

The 2011 Asian Carp Control Strategy Framework calls for USACOE to continue its feasibility study on a WabashMaumee permanent watershed separation. In addition, there is an ongoing Great Lakes and Mississippi River Inter-basin Study, part of which will explore the issue of ecological separation while reviewing alternatives to maintain commercial waterway use.

\section{Alternative 3: Commercial Harvesting}

Corral/capture/kill operations are recommended as an effective means of targeted eradication through commercial harvesting, which includes the ability for the sport fishing community to fish for the carp once they have been corralled. Previously, the Illinois Department of Natural Resources and the United States Fish and Wildlife Service routinely engaged in cor$\mathrm{ral} / \mathrm{capture} /$ kill operations in which Asian carp were corralled using electric netting and then captured and killed. In December 2009 over 2,000 pounds of Rotenone, a fish toxicant, was applied in the CSSC to kill Asian carp. The 2010 Asian Carp Control Strategy Framework recommended large-scale Rotenone application during times that the electric barriers are down for maintenance. However, the 2011 Asian Carp Control Strategy Framework is more judicious in its recommendation of large-scale deployment of toxicants, calling for the United States Geological Survey to study more targeted toxicants.

\section{Effectiveness}

Use of commercial harvesting and targeted overfishing has not been fully evaluated for effectiveness; however a catch and removal program to reduce downstream numbers of Asian carp may reduce the need for the carp to expand its habitat range. In addition, it may reduce the spawning populations. (ACWG 2011). This method would not be very effective at significantly preventing spread and does not significantly reduce the threat of migration of the Asian carp into the Great Lakes. Migration patterns indicate that even with targeted overfishing, Asian carp will continue to migrate and establish new populations.

\section{Structural Feasibility}

Targeted reduction in Asian carp populations does not require additional materials or engineered defenses and does not affect safety. Currently, Asian carp are not considered a food source in the United States, although they are served in other countries. They are extremely boney, leaving only a fraction of the fish filet useable as a dining option (Etter 2010). Despite this, there is a move to make Asian carp a more palatable dining option for US consumers. Their flavor is considered to be similar to that of sea bass.

The biggest challenge is the issue of the labor involved to reduce the amount of bones to create a good size filet, thus driving the market cost of Asian carp high. Due to the large amount of negative press, Asian carp would also need to undergo a rebranding campaign to change diner's perceptions of the fish. This rebranding has been successful in the past, for 
example the Patagonian toothfish, now renamed "Chilean Sea Bass" has become so popular it is now endangered (Vettel 2010).

\section{Political Feasibility}

While there are no legal or administrative challenges to commercial harvesting, there is little reason to believe that there is wide-spread support among all stakeholders for the for the commercial harvest alternative. Commercial harvesting, while feasible, is not considered a permanent solution to the problem. Although Illinois has signed an agreement with a fish processing plant in China for the annual purchase of up to 50 million pounds of carp harvested in Illinois, this option does not address the concerns of AIS migration via the CSSC (ACWG 2011). Commercial harvesting does not prevent the spread of Asian carp and constituents in Michigan and other Great Lakes states would find this solution to be unacceptable.

\section{Equity}

It costs Illinois an average of $\$ 2$ million per year for targeted corral and kills measures. While a majority of this funding comes from the collective Great Lakes Restoration Initiative, it is unlikely to be supported through this funding source given its low effectiveness. With estimated costs to the Great Lakes states of over $\$ 7$ billion should Asian carp establish a population, this alternative is most inequitable to the Great Lakes and its users as a whole. In addition, while commercial harvesting may appear to be a win-win solution, it may lead to overfishing and reduction of indigenous fish and could create an artificial fishery to increase Asian carp.

\section{Summary}

Table 1 shows the results of the alternatives evaluated against the criteria. All criteria were rated using a likert scale of the Asian Carp Control Strategy
Framework with equal relationships between the choices of very poor, poor, moderate, good, and very good. A scoring of one was for 'very poor,' up to a maximum scoring of five for 'very good.' The criteria scoring were added, and then divided by the number of criteria (4) to get the result.

\section{Recommendation}

There is no one-size-fits-all solution to the Asian carp problem, and it will be necessary to have cooperation among all stakeholders to solve this fishy problem (ACWG 2011). Closing the locks of the CSSC is the least viable option given that it does not meet the desired objective of creating ecological separation at the Chicago pathway and would require major structural changes to prevent floods within the Chicago basin.

Based on the above evaluation, it is recommended that stakeholders continue to support the USACOE on electric barrier fences. The electric barrier is currently the most effective and least disruptive means of controlling Asian carp migration into the Great Lakes, and is the best region-wide solution. Most notably, the electric barrier is currently the most effective means of deterring Asian carp, with an effectiveness rate of over 95 percent. In addition, this alternative is currently the most equitable for all stakeholders, with each stakeholder bearing a small portion of cost and associated risks. Illinois Department of Natural Resources and the USACOE should continue to work with adjoining Departments of Natural Resources from Great Lakes states to address best location of additional electric barrier fences to include the possibility of barriers on the lake side of the locks.

It should be recognized that an electric barrier is not the most ideal solution. As this analysis has pointed out, there are serious life safety issues associated with an electrical underwater fence. Additionally, preliminary studies have indicated that Asian carp are adapting to the electric barriers. By swimming along- 
side steel-hulled vessels, such as barges, which are transiting the barrier, it takes an average of three times longer for the fish to be stunned. It is unlikely that electric barriers are a viable, permanent solution to preventing Asian carp migration via the CSSC.

Additional deterrent methods should be evaluated, including repellants and acoustic underwater barriers. The 2011 Asian Carp Control Strategy Framework calls for the USACOE to conduct studies to establish effectiveness of the electric barriers against other measures, including through changes in the operation of locks, sluice gates, pumping stations, and how emerging technologies such as acoustic/seismic technologies may serve as fish deterrents. While these alternatives were not reviewed in this analysis, it is recommended that safer alternatives continue to be evaluated as they become available.

Table 1: Alternative and Criteria Matrix.

\begin{tabular}{|c|c|c|c|}
\hline & $\begin{array}{c}\text { Alternative: } \\
\text { Electric Barrier }\end{array}$ & $\begin{array}{l}\text { Alternative: } \\
\text { Lock Closure }\end{array}$ & $\begin{array}{c}\text { Alternative: } \\
\text { Commercial } \\
\text { Harvesting }\end{array}$ \\
\hline $\begin{array}{l}\text { Effectiveness } \\
\text { - \% Migration } \\
\text { Interruption }\end{array}$ & $\begin{array}{c}\text { (4) Good - Proven } \\
\text { effective at certain } \\
\text { voltages though not } \\
100 \%\end{array}$ & $\begin{array}{l}\text { (4) Good - Unknown } \\
\text { how flood control } \\
\text { affects migration }\end{array}$ & $\begin{array}{l}\text { (2) Poor - } \\
\text { Commercial } \\
\text { harvesting limited in } \\
\text { ability to evaluate } \\
\text { success and does not } \\
\text { prevent migration }\end{array}$ \\
\hline $\begin{array}{l}\text { Feasibility } \\
\text { Structural \& } \\
\text { Safety }\end{array}$ & $\begin{array}{l}\text { (3) Moderate - New } \\
\text { barriers being built; } \\
\text { serious concerns } \\
\text { over safety }\end{array}$ & $\begin{array}{l}\text { (2) Poor - Major } \\
\text { modifications } \\
\text { required, impacts on } \\
\text { flood/sanitation } \\
\text { control }\end{array}$ & $\begin{array}{l}\text { (5) Very Good- } \\
\text { Easy to conduct }\end{array}$ \\
\hline $\begin{array}{l}\text { Feasibility } \\
\text { Political }\end{array}$ & $\begin{array}{c}\text { (4) Good - } \\
\text { Assuming effective, } \\
\text { lake states may } \\
\text { support }\end{array}$ & $\begin{array}{c}\text { (2) Poor - Politically } \\
\text { unacceptable to } \\
\text { Illinois }\end{array}$ & $\begin{array}{c}\text { (1) Very Poor - } \\
\text { Politically } \\
\text { unacceptable to } \\
\text { Great Lakes states }\end{array}$ \\
\hline $\begin{array}{c}\text { Equity - } \\
\text { Benefits / } \\
\text { Impacts To } \\
\text { Stakeholders }\end{array}$ & $\begin{array}{l}\text { (4) Good - The } \\
\text { largest negative } \\
\text { impact is to } \\
\text { commercial vessels } \\
\text { who require an } \\
\text { escort }\end{array}$ & $\begin{array}{l}\text { (1) Very Poor- } \\
\text { Extensive economic } \\
\text { impact to Illinois \& } \\
\text { shipping }\end{array}$ & $\begin{array}{l}\text { (1) Very Poor - } \\
\text { Significant added } \\
\text { risk to Great Lakes }\end{array}$ \\
\hline Summary & $\begin{array}{c}\text { Moderate to Good } \\
3.75\end{array}$ & $\begin{array}{c}\text { Poor to Moderate } \\
2.25\end{array}$ & $\begin{array}{c}\text { Poor to Moderate } \\
2.25\end{array}$ \\
\hline
\end{tabular}

Source: Author's analysis. 


\section{References}

Asian Carp Prevention and Control Act. Pub. L. no. 111-307. 124 Stat 3282 (2010). http://thomas.loc.gov/cgi-bin/thomas.

Asian Carp Regional Coordinating Committee. 2011. "Asian Carp Control.” Accessed March 10. http://www.asiancarp.org/faq.asp\#6.

ACWG (Asian Carp Work Group). 2011. Asian Carp Control Strategy Framework. Washington, DC: Government Printing Office. http://www.asiancarp.org/Docu ments/AsianCarpControlStrategyFrameworkMay2010.pdf.

ANSTF (Aquatic Nuisance Species Task Force). 2011. "Aquatic Nuisance Species Impacts.” Accessed January 19, 2011. http://www.anstaskforce.gov/impacts.php.

Austin, John C., Soren Anderson, Paul N. Courant, and Robert E. Litan. 2007. Healthy Waters, Strong Economy: The Benefits of Restoring the Great Lakes Ecosystem. Washington, DC: Brookings Institution. Accessed January 9, 2010. http:// www.brookings.edu/metro/pubs/20070904_gleiecosystem.pdf.

Belkin, Douglas. 2010. "U.S. unveils plan to keep Asian carp out of Great Lakes.” Wall Street Journal. February 8. http://online.wsj.com/article/SB10001424052748 703630404575053931637941738.html\#articleTabs\%3Darticle.

Brammeier, Joel, Irwin Polls, and Scudder Mackey. 2008. Preliminary Feasibility of Ecological Separation of the Mississippi River and the Great Lakes to Prevent the Transfer of Aquatic Invasive Species. Alliance for the Great Lakes. Accessed March 11, 2011. http://www.greatlakes.org/Document.Doc?id=472.

Carducci, Alyssa. 2009. "The Battle to Keep Asian Carp Out of the Great Lakes.” Michigan Science 10. Accessed February 19, 2010. http://www.mackinac.org/10633.

Chicago Historical Society. 2005. "Sanitary and Ship Canal." Electronic Encyclopedia of Chicago. Accessed September 24, 2010. http://www.encyclopedia.chicagohis tory.org/pages/1684.html.

Egan, Dan. 2008. “Chicago's Electric Carp Barrier Hits a Snag.” Wall Street Journal. October, 5. http://www.jsonline.com/news/32468089.html.

Eilperin, Juliet. 2010. "Tough Choices Follow in the Wake of Many Invasive Species." Washington Post. January 31. P. A7.

Etter, Lauren. 2010. “Asian Carp Fix: Just Eat It.” Wall Street Journal. April 26. http:// online.wsj.com/article/SB10001424052748704388304575202612308114130. html.

Flesher, John. 2011. "U.S. House Rejects Proposal to Close Chicago Locks in Asian Carp Fight.” Detroit News. February 18. http://detnews.com/article/20110218/ POLITICSo3/102180400/U.S.-House-rejects-proposal-to-closeChicago-locks-in-Asian-carp-fight.

Frank, Matthew. 2010. Testimony before Congress. On Water Resources and Environment. February 29. Accessed April 25. http://www.dnr.state.wi.us/news/ mediakits/pdf/SecFrankTestimony.pdf.

Great Lakes Commission. 2009. Great Lakes Restoration Initiative: Fact Sheet. Accessed February 26, 2010. http://www.glc.org/advocacy/documents/GLRI\%20 fact\%20sheet-FAQ-May\%202009-FINAL.pdf.

Henderson, Henry, Thom Cmar, and Karen Hobbs. 2010. Re-Envisioning the Chicago River: Adopting Comprehensive Regional Solutions to the Invasive Species Crisis. Natural Resources Defense Council. Last modified September 2010. http://www.nrdc.org/water/Chicagoriver/files/Chicago\%2oRiver.pdf.

Hoddle, Mark. 2009. Quagga and Zebra Mussels. Center for Invasive Species Research. University of California, Riverside. Last modified August 14. http://cisr. 
ucr.edu/quagga_zebra_mussels.html.

Mayell, Hillary. 2002 "Maryland Wages War on Invasive Walking Fish.” National Geographic News. July 2. http://news.nationalgeographic.com/ news/2002/07/0702_020702_snakehead.html.

Michigan Sea Grant 2011. Understanding the Chicago Waterways. Last modified April 1, 2011. http://www.miseagrant.umich.edu/ais/images/Aisan-Carp-canalmap-80o.jpg.

Muench, Lynn. 2010. U.S. Coast Guard Safety Zone and Regulated Navigation Area. Letter Communication to T. Cummins. The American Waterways Operators. Last modified August 31, 2010. http://www.americanwaterways.com/index /CommentsTIRo83110.pdf.

Plumer, Harry. 2010. "Carp Big Hazard for MR340 Racer.” Columbia Missourian. Au gust 24. http://www.columbiamissourian.com/stories/2010/o8/25/carp-bighazard-mr340-racer/.

Rizo, Chris. 2010. "U.S. Supreme Court Rejects AGs Case to Close Chicago Area Locks.” Legal Newsline. January 19. http://www.legalnewsline.com/

news/225053-u.s.-supreme-court-rejects-ags-case-to-close-chicago-arealocks.

Schwieterman, Joseph P. 2010. An Analysis of the Economic Effects of Terminating Operations at the Chicago River Controlling Works and O'Brien Locks on the Chicago Area Waterway System. Chicago: DePaul University. Last modified April 7. http://www.unlockourjobs.org/wp-content/themes/unlockourjobs/ pdf/DePaul_University_Study.pdf.

Stabenow, Debbie. n.d. "Permanent Prevention of Asian Carp Act.” Accessed March 10, 2011. http://stabenow.senate.gov/?p=issue\&id=63.

Shea, Chuck. 2009. Chicago Sanitary and Ship Canal Aquatic Nuisance Species Dispersal Barriers. US Army Corps of Engineers. Accessed April 14, 2010. http:// www.lrc.usace.army.mil/projects/fish_barrier/(site requires log in).

Taylor, John C. and James L. Roach. 2010. Review of Chicago Waterway System Ecological Separation: The Logistics and Transportation Related Cost Impact of Waterway Barriers. Lansing, Michigan: Department of Attorney General. Last modified February 2, 2010. http://www.greatlakeslaw.org/files/mich_carp_ renewed_appendix.pdf.

University of Wisconsin, Sea Grant Institute. n.d. "Dispersal Barrier.” Aquatic Nuisance Species. http://www.seagrant.wisc.edu/ais/Default.aspx?PageContentI $\mathrm{D}=261 \&$ tabid $=393$ (

US Army Corps of Engineers (USACOE). 2010. Great Lakes and Mississippi Inter-basin Study: Other Pathways Preliminary Risk Characterization. Accessed January 25, 2011. http://www.lrc.usace.army.mil/pao/GLMRIS-OtherPathway sExecutiveSummary.pdf.

---. 2011. Fiscal Year 2012 Civil Works Budget for the US Army Corps of Engineers. Last modified February 11. http://www.usace.army.mil/CECW/PID/

Documents/budget/budget2012.pdf.

US Coast Guard. n.d. "Fish Barrier Information." Fish Barrier Information. Accessed April 5, 2010. http://www.uscg.fishbarrierinfo.com/go/site/1295/ (site not accessible to the public).

US Congress. 2010. Close All Routes and Prevent Asian Carp Today Act of 2010. H.R. 4472, 111th Congress. Washington, DC: Library of Congress. Accessed January 25. http://thomas.loc.gov/cgi-bin/query/z?c111:H.R.4472:.

US Department of Agriculture. 2010. “Aquatic Species.” National Invasive Species In- 
formation Center. Last modified December 21. http://www.invasives peciesinfo.gov/aquatics/economic.shtml.

US Geological Survey. 2005. “Bighead Carp.” Florida Integrated Science Center. Ac cessed March 1, 2010. http://fisc.er.usgs.gov/Carp_ID/html/hypophthalmich thys_nobilis.html.

Vettel, Phil. 2010. “That Pesky Asian Carp: It's What's for Dinner.” Chicago Tribune. April 22. http://articles.chicagotribune.com/2010-04-22/entertainment/ct -play-0422-vettel-asian-carp-taste-20100421_1_carp-sea-bass-fish.

Walsh, Bryan. 2010. “Lake Invaders.” Time. August 23. http://www.time.com/time/ magazine/article/o,9171,2010202,oo.html.

Wisconsin v. Illinois. 281 U.S. 696 (1930).

Nicole Rodriguez is a Lieutenant Commander in the US Coast Guard. She received her Master of Public Administration with a concentration in emergency management from The George Washington University in 2010. She earned her BA at James Madison University with a major in anthropology. Nicole is married to Kevin Rodriguez and they have two children, Erik Michael and Sophia.

The author thanks editors Jeff Williams, J. Perry Yates, Kaitlin Welborn, and Andrea Leung for their valuable feedback and encouragement, and ADM Thad Allen for his thoughtful edits. Finally, the author would like to thank her dad, CAPT D. Mike Smith, as well as ADM Peter Neffenger, CDR Amy Beach, and LCDR Erik Pickering who have been patient enough to discuss Asian carp endlessly; it's time for a fish fry! 